\title{
Globalism after COVID-19 Pandemic: A Turning Point in the Separation of Social and Economic Aspects
}

\author{
Kaleh Karim ${ }^{1,2}$, Sujata Guha1, Ryan Beni ${ }^{*}$ \\ ${ }^{1}$ Department of Chemistry, Tennessee State University, Nashville, TN, USA \\ ${ }^{2}$ Department of Biological Sciences, Tennessee State University, Nashville, TN, USA \\ Email: ^rbeni@tnstate.edu
}

How to cite this paper: Karim, K., Guha, S., \& Beni, R. (2020). Globalism after COVID-19 Pandemic: A Turning Point in the Separation of Social and Economic Aspects. Voice of the Publisher, 6, 7-17. https://doi.org/10.4236/vp.2020.62002

Received: April 13, 2020

Accepted: June 1, 2020

Published: June 4, 2020

Copyright $\odot 2020$ by author(s) and Scientific Research Publishing Inc. This work is licensed under the Creative Commons Attribution International License (CC BY 4.0).

http://creativecommons.org/licenses/by/4.0/

\section{(c) (i) Open Access}

\begin{abstract}
A global pandemic caused by a microscopic enemy, which outbroke in Wuhan, China, quickly spread throughout the modern world, bringing world's largest economies to a halt. By March 2020, the whole world was impacted by the ripple effects of COVID-19 and was in the midst of battling this infectious disease. The pervasive economic consequences of the coronavirus are not a macroeconomic problem that can be solved or reduced. Instead, the world is seeing a fundamental change in the nature of the global economy. The immediate crisis is considered to have affected both supply and demand. Declining supply shall be considered as a short-term issue, that stimulus plans by various countries, including a massive plan by the US government, along with historic low interest rates, may remedy. In this article we examine different scenarios of the supply chain's future and its separation from social trends. Moving nations toward self-sufficiency may deeply alter globalization, which requires the division of labor between different economies. Unless strong economic policy measures are taken to prevent social disintegration, this change may be an end to globalization. Hence, many global leaders have implemented stimulus packages in an effort to relieve the economic stress felt by businesses and families, as a short-term economic stress relief. This pandemic has demonstrated the fragile nature of the US and the global trade system, due to majority of products being manufactured in China. There is an urgent need to expand manufacturing industries to various countries rather than concentrate most of them in one location. This pandemic will result in a shift to self-sufficiency, in the short-term, within borders. However, in the long-run, it will re-define globalization to include more countries functioning as micro-hubs for production, which should be implemented to avoid the "all eggs in one basket" scenario. In addition, this system will enable smaller economies to participate in the global platform.
\end{abstract}




\section{Keywords}

COVID-19, Coronavirus, Socioeconomic, Supply Chain, Pandemic, Nationalism, Globalization

\section{Introduction (COVID-19)}

First identified in Wuhan, China in December 2019, Coronavirus Disease 2019 or COVID-19 (Figure 1) is an infectious disease related to the severe acute respiratory syndrome coronavirus 2 (SARS-CoV-2) strain (Hui et al., 2020; Ghebreyesus, 2020; WHO, 2020). SARS-CoV-2 is a positive-sense single-stranded RNA virus, where the positive-sense RNA strand can insert into the human host genome and serve as a messenger RNA to be translated into the viral protein in host cells (Baltimore, 1971). Like other positive-strand RNA viruses, such as Severe Acute Respiratory Syndrome (SARS) and Middle East Respiratory Syndrome (MERS), COVID-19 causes acute respiratory infection leading to viral pneumonia (Hui et al., 2020; Lu et al., 2020; World Health Organization Q\&A, 2020). Although healthy individuals may possess mild to moderate symptoms, immunocompromised elderly patients and those with underlying medical conditions, such as diabetes and heart disease, are more likely to develop severe symptoms leading to viral pneumonia and multiple organ failure induced by the impaired respiratory function starving organ cells from oxygen supply (World Health Organization Q\&A, 2020; Centers for Disease Control and Prevention, 2020). According to the Worldometer estimates, more than 1.5 million individuals have contracted COVID-19, resulting in more than 90,000 deaths, worldwide (Worldometer, 2020).

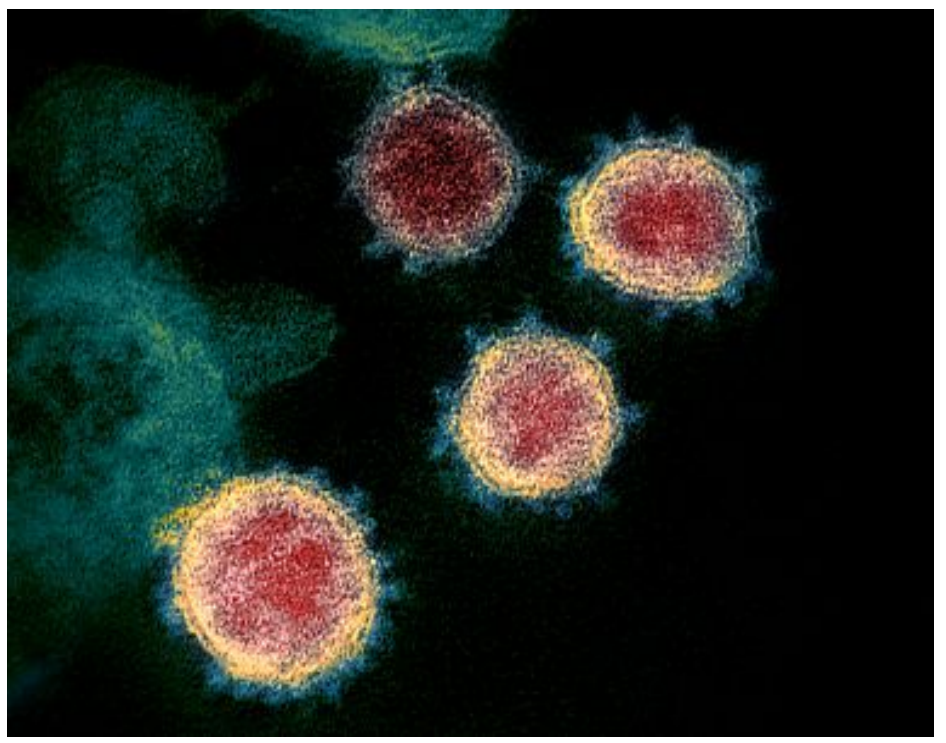

Figure 1. Electron microscope image of coronavirus isolated from a patient in the United States (National Institute of Health, 2020). 
COVID-19 is zoonotic disease, which is believed to have come from bats, and passed though intermediary animal prior to infecting humans. Phylogenetic studies revealed nucleotide homology between isolates from human subjects and horseshoe bats (Rhinolophus ferrumequnum) (Lu et al., 2020; Zhou et al., 2020; Ren et al., 2020), leading scientists to believe that the virus, which was not capable of infecting human host originally, entered its intermediary host (pangolin, pangolins are mammals of the order Pholidota), where a chimeric evolution occurred giving rise to a viral strain capable of infecting the human host. One study has ruled out pangolins as an intermediary, on the basis of missing the RRAR motif in isolates taken from pangolins ( $\mathrm{Li}$ et al., 2020). Hence, the direct origins of the virus are still being studied. The search for patient zero has linked 27 of the early COVID-19 patients to the Huanan Seafood Wholesale Market, leading to the hypothesis that the COVID-19 virus was originally transmitted from a living animal to a human host. The virus has since spread like wildfires, causing a global pandemic.

The primary symptoms of the COVID-19 include cough, fever, tiredness, and in severe cases, breathing difficulty. The most striking attribute of COVID-19 is the incubation period, which has been shown to have a median of 5.1 days, with 97.5\% of patients having developed symptoms within 11.5 days (Lauer et al., 2020). COVID-19 can spread via air droplets when a patient coughs or sneezes, when they are symptomatic and even when asymptomatic. Due to disparities among different minority groups and low-income groups, deaths related to COVID-19 have been of particular concern in the US and globally. In India, the poor communities have been the hardest hit with the COVID-19's health and economic burden (Al Jazeera, 2020). In the US, Chicago and Louisiana have had the highest death rates among African American minority groups accounting for $70 \%$ of total deaths even though, African Americans account for about 30\% of the overall populations in those states. In Michigan, African Americans comprise $14 \%$ of the overall population; however, they account for $40 \%$ of overall COVID-19 deaths (Milwaukee County Covid-19 Dashboard, 2020; Louisiana Department of Health, 2020; Michigan Government, 2020; Illinois Department of Public Health, 2020). These statistics further demonstrate the health burden associated with socioeconomic background and racial disparities, and the need for availability of special services in minority communities. This calls for framework studies to analyze ways for fair distribution of resources to all communities, in an effort to reduce disparities.

\section{A Brief History of Pandemics}

The history of global trade may go back to about 130 BC when the Silk Road was initially established. The Silk Road was not a single thoroughfare from east to west. The term "Silk Routes" has become increasingly favored by historians, though "Silk Road" is the more common and recognized name. Originating at Xi'an (Sian), the 4000-mile (6400-km) caravan tract followed the Great Wall of China to the northwest, bypassed the Takla Makan Desert, climbed the Pamir mountains, crossed Afghanistan, and went on to the Levant; from where merchandise was shipped 
across the Mediterranean Sea (Figure 2). Few persons traveled the entire route, and goods were handled in a staggered progression by middlemen (Encyclopedia Britannica, 2020). With the gradual loss of Roman territory in Asia and the rise of Arabian power in the Levant, the Silk Road became increasingly unsafe and untraveled. In the $13^{\text {th }}$ and $14^{\text {th }}$ centuries, the route was revived under the Mongols, and at that time Marco Polo used it to travel to Cathay (China). It is now widely thought that the route was one of the main ways that plague bacteria, responsible for the Black Death pandemic in Europe in the mid-14 ${ }^{\text {th }}$ century, moved westward from Asia (Gould, 1966). The Black Death was the most devastating pandemic recorded in human history, resulting in the annihilation of up to 75 125 million people across the world (Dunham, 2008). Diseases and illnesses have plagued humanity since the earliest days. However, it was not until the marked shift to agrarian communities that the scale and spread of these diseases increased dramatically. Widespread trade created new opportunities for human and animal interactions that sped up such epidemics. Malaria, tuberculosis, leprosy, influenza, smallpox, and other diseases first appeared during these early years.

In recent decades, the aviation industry has been the leading carrier of widespread infectious viruses, such as seasonal flus, Swine flu, SARS, MERS and the novel Coronavirus.

According to Flightradar24, a leading global flight tracking service that provides real-time aircraft information on a map, commercial aviation reached an all-time record high on 25 July 2019, with more than 230,000 flights in a single day (Flight Radar 24, 2008). Figure 3 shows a typical real-time commercial aircraft flight tracking information across the globe.

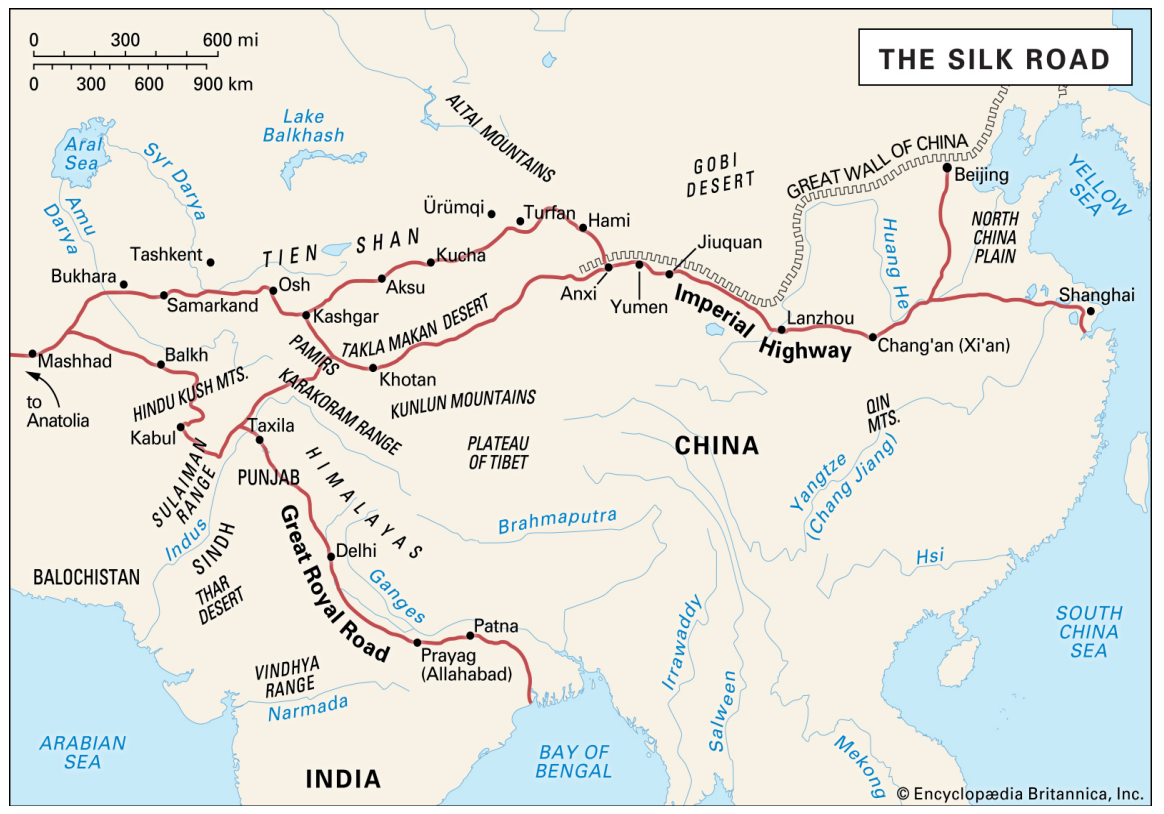

Figure 2. Silk Road, the ancient trade route, linking China with the West (Encyclopedia Britannica, 2020). The Black Death pandemic in Europe in the mid-14th century was linked to Silk Road (Gould, 1966; Dunham, 2008). 


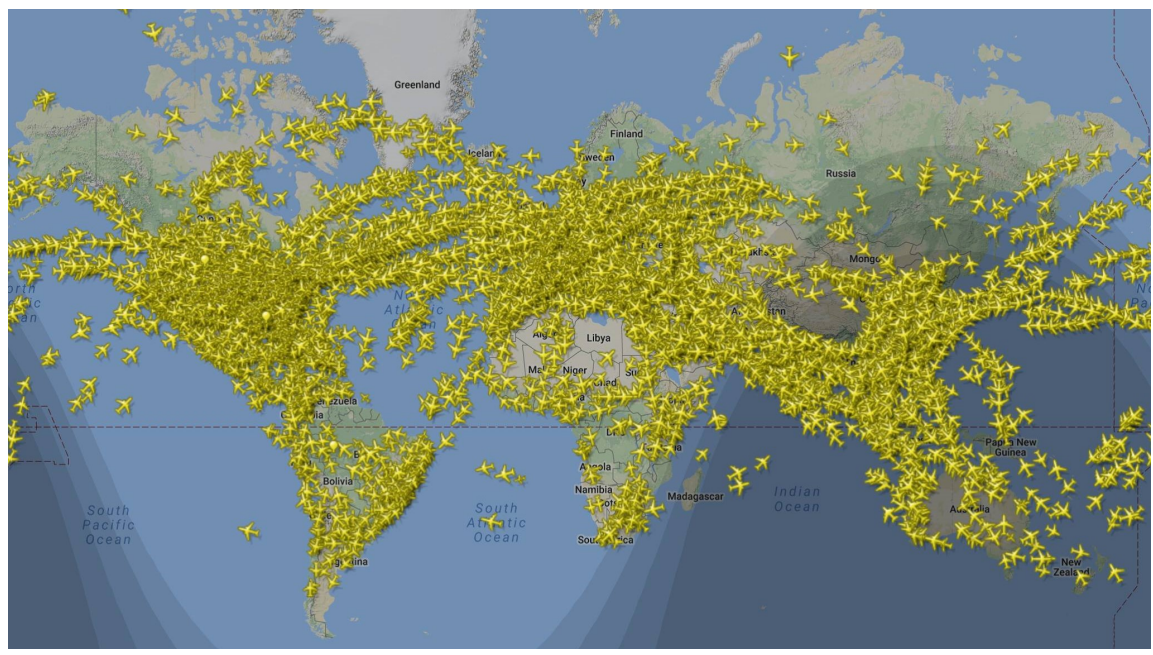

Figure 3. Typical real-time commercial aircraft flight traffic, shown by Flightradar24 (Flight Radar 24, 2008).

Since the inception of the Silk Route, civilization has expanded involving exotic trade routes and increased contact with different people, animals, and ecosystems, leading to a likelihood of pandemics (LePan, 2020). Table 1 lists some of the major pandemics that have occurred over time.

\section{Future of Globalization}

Urbanization in the developing world is bringing more and more rural residents into denser neighborhoods, while population increases are putting greater pressure on the environment. At the same time, passenger air traffic nearly doubled in the past decade. These macro trends are having a profound impact on the spread of infectious disease (LePan, 2020). The world economy has seen globalization collapse once already. The gold standard era with its free capital mobility and open trade ended abruptly in 1914 and could not be resuscitated after the First World War. It is unclear whether we are about to witness a similar global economic breakdown after the massive pandemic started in year 2020, and, if globalization is in danger, who its real enemies are.

\subsection{Global Manufacturing Hubs and Supply Chains}

There was a time when global elites could comfort themselves with the thought that opposition to the world trading regime consisted of violent anarchists, selfserving protectionists, trade unionists, and ignorant, if idealistic youth. The elites regarded themselves as the true progressives, because they understood that safeguarding and advancing globalization was the best remedy against poverty and insecurity (Rodrick, 2020). A survey of literature reveals that there is a flood of compelling articles indicating that the post-coronavirus world may be the end of globalization (Rapoza, (March) 2020a). There are similar convincing reports implying that coronavirus could be the end of China as a global manufacturing hub (Rapoza, (April) 2020b). The new coronavirus, COVID-19, will end up being the final curtain on China's nearly 30 -year role as the world's leading manufacturer. 
Table 1. A timeline of historical pandemics ${ }^{\mathrm{a}, \mathrm{b}}$.

\begin{tabular}{|c|c|c|c|}
\hline Name & Time period & Type/Pre-human host & Death toll \\
\hline Antonine Plague & $165-180$ & Believed to be either smallpox or measles & $5 \mathrm{M}$ \\
\hline Japanese smallpox epidemic & $735-737$ & Variola major virus & $1 \mathrm{M}$ \\
\hline Plague of Justinian & $541-542$ & Yersinia pestis bacteria/Rats, fleas & $30-50 \mathrm{M}$ \\
\hline Black Death & $1347-1351$ & Yersinia pestis bacteria/Rats, fleas & $200 \mathrm{M}$ \\
\hline New World Smallpox Outbreak & 1520-onwards & Variola major virus & $56 \mathrm{M}$ \\
\hline Great Plague of London & 1665 & Yersinia pestis bacteria/Rats, fleas & 100,000 \\
\hline Italian plague & $1629-1631$ & Yersinia pestis bacteria/Rats, fleas & $1 \mathrm{M}$ \\
\hline Cholera Pandemics 1 - 6 & $1817-1923$ & $V$. cholerae bacteria & $1 \mathrm{M}+$ \\
\hline Third Plague & 1885 & Yersinia pestis bacteria/Rats, fleas & $12 \mathrm{M}$ (China and India) \\
\hline Yellow Fever & Late $1800 \mathrm{~s}$ & Virus/Mosquitoes & $100,000-150,000$ (U.S.) \\
\hline Russian Flu & $1889-1890$ & Believed to be $\mathrm{H} 2 \mathrm{~N} 2$ (avian origin) & $1 \mathrm{M}$ \\
\hline Spanish Flu & 1918-1919 & H1N1 virus/Pigs & $40-50 \mathrm{M}$ \\
\hline Asian Flu & $1957-1958$ & $\mathrm{H} 2 \mathrm{~N} 2$ virus & $1.1 \mathrm{M}$ \\
\hline Hong Kong Flu & $1968-1970$ & $\mathrm{H} 3 \mathrm{~N} 2$ virus & $1 \mathrm{M}$ \\
\hline HIV/AIDS & 1981-present & Virus/Chimpanzees & $25-35 \mathrm{M}$ \\
\hline Swine Flu & $2009-2010$ & H1N1 virus/Pigs & 200,000 \\
\hline SARS & $2002-2003$ & Coronavirus/Bats, Civets & 770 \\
\hline Ebola & 2014-2016 & Ebolavirus/Wild animals & 11,000 \\
\hline MERS & 2015-Present & Coronavirus/Bats, camels & 850 \\
\hline COVID-19 & 2019-Present & Coronavirus-Unknown (possibly pangolins) & $323,000^{c}$ \\
\hline
\end{tabular}

a Table adopted from reference (LePan, 2020). ${ }^{b}$ Many of the death toll numbers listed above are best estimates based on available research. Some, such as the Plague of Justinian and Swine Flu, are subject to debate based on new evidence. 'Johns Hopkins University estimate as of 6:35 am PT, May 19, 2020.

China's economy is getting hit much harder by the coronavirus outbreak than markets currently recognize. The most frightening aspect of this crisis is not the short-term economic damage it is causing, but the potential long-lasting disruption to supply chains. Chinese auto manufacturers and chemical plants have reported more closures than other sectors (Arena, 2020).

China may be losing its prowess as the global leader in manufacturing, even though, it was moving at a panda bear's pace, mostly because companies try to do business with countries having the lowest costs of labor and production (Qazi, 2020). To control the spread of COVID-19, governments around the globe have closed borders in an effort to flatten the curve, lower infection rates, and ultimately stop the spread of this virus. In this process, many industries have been severely impacted. Table 2, summarizes the industries that have been most heavily affected by the pandemic. These industries are likely going to suffer the consequences of this pandemic for a long period of time as individuals who have lost their jobs may not be able to secure a job sooner hence, reducing travel and recreational activities. 
Table 2. Industries most heavily impacted by the COVID-19 pandemic.

\begin{tabular}{cl}
\hline Countries & \multicolumn{1}{c}{ Industries } \\
\hline USA & Leisure, hospitality, travel services, transportation, automakers, oil and gas extraction \\
Italy & Food, manufacturing and tourism \\
France & Tourism and hospitality \\
Spain & Tourism and hospitality \\
China & Recreation, transportation, trade and communication services, motor vehicles and parts \\
Germany & Tourism and hospitality
\end{tabular}

The repercussions of the trade war are already being felt in Mexico (Arena, 2020). Mexico replaced China as the U.S. leading trading partner, although China had overtaken Mexico for a short while. Although reports indicate China's resilience to return to massive manufacturing, other countries like Vietnam seem to be competing to share that platform, as indicated by the recent shipment of 450,000 Tyvek $^{\circledR}$ medical protective suits to the United States (WMC, 2020). Vietnam will be shipping more than 500,000 more protective suits in the coming weeks which could be the steppingstone for a new manufacturing partnership between the U.S. and Vietnam, in addition to Bangladesh and India.

\subsection{Disproportional Socioeconomic Impacts (A Fragile World)}

The pandemic and its aftermath could be a game-changer for poorer countries with limited resources and means of recovery and could affect refugees and people in conflict zones in a negative manner (Tisdall, 2020). According to the International Crisis Group (ICG), the outbreak COVID-19 has the potential to wreak havoc in fragile states and trigger widespread unrest globally (International Crisis Group, 2020). It may be virtually impossible to control the disease, if it spreads in densely packed urban centers. The report from the ICG stated that dramatic global economic slowdown would disrupt trade flows and create unemployment in commodity-exporting poorer countries. Its implications would be especially serious for those caught amid conflict, if humanitarian aid flows are disrupted, peace operations are limited, and diplomatic missions are postponed due to the Coronavirus disease (Burke, 2020).

The human toll of the pandemic is the most important cost and the one that could lead to societal disintegration. Those who are left hopeless, jobless, and without assets could easily turn against those who are better off. Already, some 30 percent of Americans have zero or negative wealth. If more people emerge from the current crisis with neither money, nor jobs, nor access to health care, and if such people become desperate, events similar to the looting that followed Hurricane Katrina in New Orleans in 2005, might become commonplace. If governments must resort to using paramilitary forces to quell, for example, riots or attacks on property, societies could begin to disintegrate (Milanovic, 2020). 
Pandemics may disproportionately hurt the poor (Vesoulis, 2020), but if people from low-income communities are negatively impacted, it could spell bad news for middle- and upper-income families, too. A study found that socioeconomic differences among individuals who contracted the 1918 Spanish Flu ended up playing a key role in survival rates. The poor people were the first to contract influenza, while the rich has the death rates in the following years, although they initially had less exposure to the disease (Mamelund, 2018; Allen et al., 2020). It is critical for lawmakers to work together at this time to combat the Coronavirus outbreak and implement measures to safeguard and assist the population as much as possible.

\section{Conclusion}

The coronavirus pandemic evolved from a health crisis to a financial one, shattering businesses, upending entire industries, and sending financial markets reeling. These are the short-term and mostly reversible impacts on societies. The longlasting impacts on international trade, wealth disparities, and manufacturing hubs and supply chains need to be redefined. China's economy is characterized based on globalism, and the country is committed to saving the globalized system. However, the coronavirus pandemic could be the beginning of the end of economic globalization. It is highly unlikely that the world will return to the idea of mutually beneficial global development that was defined in the early $21^{\text {st }}$ century. Without an incentive to support common interests against global economic integration, the architecture of global economic sovereignty, established in the twentieth century, will quickly degenerate. This pandemic may lead to the isolationism among different countries, which will not only impede economic growth, but also lower growth potential and innovation. Although a temporary global shut down is necessary to slow the spread of this virus, it is not a permanent avenue. More than ever, political leaders must come together to invest in and explore channels to become better prepared for infectious outbreaks with improved monitoring techniques and vaccine development to prevent casualties without risking the economy.

\section{Conflicts of Interest}

The authors declare no conflicts of interest regarding the publication of this paper.

\section{References}

Al Jazeera (2020). News/India. "Future Is Scary": Poor Hit Hardest by India's Coronavirus Lockdown.

https://www.aljazeera.com/news/2020/04/scary-poor-hit-hardest-india-coronavirus-loc kdown-200409105651819.html

Allen, J., Burns, N., Garrett, L., Haass, R., Ikenberry, G. J., Mahbubani, K., Menon, S., Niblett, R., Nye Jr., J., O'Niel, S., Schake, K., \& Walt, S. (2020). How the World Will Look after the Coronavirus Pandemic.

https://foreignpolicy.com/2020/03/20/world-order-after-coroanvirus-pandemic 
Arena, F. (2020). International Trade and Trends in Mexico: Survey Report. https://www.foley.com/en/-/media/files/insights/publications/2020/02/final-2020-foley -trade-survey-report.pdf

Baltimore, D. (1971). Expression of Animal Virus Genomes. Bacteriology Reviews, 35, 235-241. https://doi.org/10.1128/MMBR.35.3.235-241.1971

Burke, J. (2020). Coronavirus Cases in Africa Pas 2,400 amid Fears for Health Services. https://www.theguardian.com/world/2020/mar/25/coronavirus-cases-africa-pass-amidfears-health-services-south-who

Centers for Disease Control and Prevention (2020). Symptoms of Coronavirus. https://www.cdc.gov/coronavirus/2019-ncov/symptoms-testing/symptoms.html?CDC AA_refVal=https\%3A\%2F\%2Fwww.cdc.gov\%2Fcoronavirus\%2F2019-ncov\%2Fabout \%2Fsymptoms.html

Dunham, W. (2008). Black Death “Discriminated” between Victims. ABC Science. http://www.abc.net.au/science/articles/2008/01/29/2149185.htm

Encyclopedia Britannica (2020). Silk Road: Trade Route. https://www.britannica.com/topic/Silk-Road-trade-route

Flight Radar 24 (2008). https://www.flightradar24.com/blog/then-and-now-visualizing-covid-19s-impact-on-ai r-traffic

Ghebreyesus, T. A. (2020). World Health Organization Director-General's Opening Remarks at the Media Briefing on COVID-19, 11 March 2020.

https://www.who.int/dg/speeches/detail/who-director-general-s-opening-remarks-at-t he-media-briefing-on-covid-19---15-may-2020

Gould, G. M. (1966). Anomalies and Curiosities of Medicine (p. 617). Philadelphia, PA: Blacksleet River.

Hui, D. S., I. Azhar, E., Madani, T. A., Ntoumi, F., Kock, R., Dar, O., Ippolito, G., Mchugh, T. D., Memish, Z. A., Drosten, C., Zumla, A., \& Petersen, E. (2020). The Continuing 2019-nCoV Epidemic Threat of Novel Coronaviruses to Global Health-The Latest 2019 Novel Coronavirus Outbreak in Wuhan, China. International Journal of Infectious Diseases, 91, 264-266. https://doi.org/10.1016/j.ijid.2020.01.009

Illinois Department of Public Health (2020). http://www.dph.illinois.gov/covid19/covid19-statistics

International Crisis Group (2020). COVID-19 and Conflict: Seven Trends to Watch. https://www.crisisgroup.org/global/sb4-covid-19-and-conflict-seven-trends-watch

Lauer, S. A., Grantz, K. H., Bi, Q, Jones, F. K., Zheng, Q., Meredith, H. R., Azman, A. S., Reich, N. G., \& Lessler, J. (2020). The Incubation Period of Coronavirus Disease 2019 (COVID-19) from Publicity Reported Confirmed Cases: Estimation and Application. Annals of Internal Medicine, 172, 577-582. https://doi.org/10.7326/M20-0504

LePan, N. (2020). Visualizing the History of Pandemics. Visual Capitalist. https://www.visualcapitalist.com/history-of-pandemics-deadliest

Li, X., Zai, J., Zhao, Q., Nie, Q., Li, Y., Foley, B. T., \& Chaillon, A. (2020). Evolutionary History, Potential Intermediate Animal Host, and Cross-Species Analyses of SARS-CoV-2. Journal of Medical Virology, 892, 602-611.

https://doi.org/10.1002/jmv.25731

Louisiana Department of Health (2020). Coronavirus (COVID-19). http://ldh.la.gov/coronavirus

Lu, R., Zhao, X., Li, J., Niu, P., Yang, B., Wu, H., Wang, W., Song, H., Huang, B., Zhu, N., Bi, Y., Ma, X., Zhan, F., Wang, L., Hu, T., Zhou, H., Hu, Z., Zhou, W., Zhao, L., Chen, J., 
Meng, Y., Wang, J., Lin, Y., Yuan, J., Xie, Z., Ma, J., Liu, W. J., Wang, D., Xu, W., Holmes, E. C., Gao, G. F., Wu, G., Chen, W., Shi, W., \& Tan, W. (2020). Genomic Characterisation and Epidemiology of 2019 Novel Coronavirus: Implications for Virus Origins and Receptor Binding. The Lancet, 395, 565-574.

https://doi.org/10.1016/S0140-6736(20)30251-8

Mamelund, S.-E. (2018). 1918 Pandemic Morbidity: The First Wave Hits the Poor; the Second Wave Hits the Rich. Influenza and Other Respiratory Viruses, 12, 307-313. https://doi.org/10.1111/irv.12541

Michigan Government (2020). Coronavirus/Michigan Data. https://www.michigan.gov/coronavirus/0,9753,7-406-98163_98173---,00.html

Milanovic, B. (2020). The Real Pandemic Danger Is Social Collapse: As the Global Economy Come Apart, Societies May, Too. Foreign Affairs.

https://www.foreignaffairs.com/articles/2020-03-19/real-pandemic-danger-social-collapse

Milwaukee County COVID-19 Dashboard (2020). Milwaukee County Coronavirus Disease (COVID-19) Cases.

https://www.arcgis.com/apps/opsdashboard/index.html\#/018eedbe075046779b8062b5f e1055bf

National Institute of Health (2020). Novel Coronavirus Structure Reveals Targets for Vaccines and Treatments.

https://www.nih.gov/news-events/nih-research-matters/novel-coronavirus-structure-re veals-targets-vaccines-treatments

Qazi, S. (2020). Coronavirus Is Hitting China's Economy Harder than Expected. https://www.barrons.com/articles/coronavirus-hit-chinas-economy-worse-than-expect ed-china-beige-book-51582902867

Rapoza, K. (2020a). Coronavirus Could Be the End of China as a Global Manufacturing Hub. https://www.forbes.com/sites/kenrapoza/2020/03/01/coronavirus-could-be-the-end-ofchina-as-global-manufacturing-hub/\#2d5b9e6b5298

Rapoza, K. (2020b). The Post-Coronavirus World May Be the End of Globalization. Forbes. https://www.forbes.com/sites/kenrapoza/2020/04/03/the-post-coronavirus-world-maybe-the-end-of-globalization/\#36d691ba7e66

Ren, L. L., Wang, Y. M., Wu, Z. Q., Xiang, Z. C., Guo, L., Xu, T., Jiang, Y. Z., Xiong, Y., Li, Y. J., Li, X. W., Li, H., Fan, G. H., Gu, X. Y., Xiao, Y., Gao, H., Xu, J. Y., Yang, F., Wang, X. M., Wu, C., Chen, L., Liu, Y. W., Liu, B., Yang, J., Wang, X. R., Dong, J., Li, L., Huang, C. L., Zhao, J. P., Hu, Y., Cheng, Z. S., Liu, L. L., Qian, Z. H., Qin, C., Jin, Q., Cao, B., \& Wang, J. W. (2020). Identification of a Novel Coronavirus Causing Severe Pneumonia in Human: A Descriptive Study. Chinese Medical Journal, 133, 1015-1024. https://doi.org/10.1097/CM9.0000000000000722

Rodrick, D. (2020). No Cheers for Globalization. The Guardian. https://www.theguardian.com/commentisfree/2008/jul/31/economy.globalisation

Tisdall, S. (2020). Power, Equality, Nationalism: How the Pandemic Will Reshape the World.

https://www.theguardian.com/world/2020/mar/28/power-equality-nationalism-how-th e-pandemic-will-reshape-the-world

Vesoulis, A. (2020). Coronavirus May Disproportionately Hurt the Poor-And That's Bad for Everyone. https://time.com/5800930/how-coronavirus-will-hurt-the-poor

WMC (2020). FedEx Partners with Federal Government to Expedite Shipping of PPE, Other Medical Supplies.

https://www.wmcactionnews5.com/2020/04/08/fedex-partners-with-federal-governme nt-expedite-shipping-ppe-other-medical-supplies 
World Health Organization (WHO) (2020). Naming the Coronavirus Disease (COVID-19) and the Virus that Causes It.

https://www.who.int/emergencies/diseases/novel-coronavirus-2019/technical-guidance /naming-the-coronavirus-disease-(covid-2019)-and-the-virus-that-causes-it

World Health Organization Q\&A (2020). Q\&A on Coronaviruses (COVID-19). https://www.who.int/news-room/q-a-detail/q-a-coronaviruses

Worldometer (2020). COVID-19 Coronavirus Pandemic. https://www.worldometers.info/coronavirus/?utm_campaign=homeAdvegas1

Zhou, P., Yang, X. L., Wang, X. G., Hu, B., Zhang, L., Zhang, W., Si, H. R., Zhu, Y., Li, B., Huang, C. L., Chen, H. D., Chen, J., Luo, Y., Guo, H., Jiang, R. D., Liu, M. Q., Chen, Y., Shen, X. R., Wang, X., Zheng, X. S., Zhao, K., Chen, Q. J., Deng, F., Liu, L. L., Yan, B., Zhan, F. X., Wang, Y. Y., Xiao, G. F., \& Shi, Z. L. (2020). A Pneumonia Outbreak Associated with a New Coronavirus of Probable Bat Origin. Nature, 579, 270-273.

https://doi.org/10.1038/s41586-020-2012-7 